\title{
Annulatascus fusiformis sp. nov., a new freshwater ascomycete from the Philippines
}

\author{
Kevin D. Hyde ${ }^{1}$ \\ Sze-Wing Wong \\ Centre for Research in Fungal Diversity, Department of \\ Ecology and Biodiversity, The University of Hong \\ Kong, Pokfulam Road, Hong Kong
}

\begin{abstract}
Annulatascus fusiformis sp. nov. is described based on a specimen collected on submerged wood from a river in the Philippines. The species possesses globose to subglobose, black, immersed ascomata with long hyaline necks; wide, septate, tapering paraphyses, and cylindrical unitunicate asci with a relatively massive refractive apical ring. In this respect it is similar to species of Annulatascus, however, $A$. $f u$ siformis differs from other species in the genus, as ascospores are provided with bipolar mucilaginous pad-like appendages. The species is illustrated with light, scanning and electron micrographs.

Key Words: Annulatascaceae, appendages, aquatic fungi, new species, taxonomy
\end{abstract}

In a continuing study of freshwater Annulatascus-like species in the tropics (Hyde et al 1998, Goh et al 1999, Wong et al 1999a), an undescribed species was collected on submerged wood in the Philippines. $A n$ nulatascus K. D. Hyde presently includes 7 species (Ho et al 1999a, b), all from freshwater habitats in the tropics. Annulatascus fusiformis sp. nov. differs from other Annulatascus species, as the ascospores have bipolar mucilaginous pad-like appendages. At the transmission electron microscope (TEM) level, the mucilaginous pad comprises electron-dense material that completely surrounds the ascospore, albeit thinner in the center of the ascospore. The morphological differences between A. fusiformis and other species in the genus are discussed.

Partially decomposed decorticated submerged wood was collected from Natigbasan Creek, Impalutao, Bukidnon, in the Philippines and returned to the laboratory in Hong Kong, where it was incubated at room temperatue $(\sim 22 \mathrm{C})$ in moist plastic boxes and examined within $4 \mathrm{wk}$ for fungal fruiting bodies. Fruiting structures were then prepared for further

Accepted for publication November 23, 1999.

${ }^{1}$ Email: kdhyde@hkucc.hku.hk study at the light, scanning and transmission electron microscope levels, following the methods of Wong et al (1999b). Single spore isolations were attempted, but the ascospores did not germinate.

Annulatascus fusiformis K. D. Hyde et S. W. Wong, sp. nov FIGS. 1-19

Ascomata 170-220 $\mu \mathrm{m}$ diam, immersa vel semi-immersa, globosa vel subglobosa, nigra, coriacea, papillata, paraphysata, periphysata. Asci 141-235 × 7.5-10.5 $\mu \mathrm{m}$, 8-spori, longe-cylindrici, pedicellati, apparato apicale, 4-5 $\mu \mathrm{m}$ longi, 3-4 $\mu \mathrm{m}$ diam praediti. Ascosporae 16.5-25.5 $\times 6-9 \mu \mathrm{m}$, uniseriatae, fusiformes, hyalinae, 1-5-septatae, verruculosae, appendiculatae.

Ascomata 170-220 $\mu \mathrm{m}$ diam, immersed or semi-immersed, globose to subglobose, black, coriaceous and solitary. Neck long, brown to black, periphysate, with a hyaline apex (FIG. 1). Peridium comprising several layers of thick, brown-walled compressed cells, hyaline and elongate inwardly. Paraphyses up to $7.5 \mu \mathrm{m}$ wide, filamentous, numerous, constricted at the septa and tapering distally (FIG. 6). Asci 141-235 $\times 7.5-$ $10.5 \mu \mathrm{m}(\bar{x}=180 \times 8.8 \mu \mathrm{m}, \mathrm{n}=25), 8$-spored, longcylindrical, with a tapering base (FIGS. 4, 5) and a relatively massive, refractive, bipartite, apical ring, 4$5 \mu \mathrm{m}$ long, 3-4 $\mu \mathrm{m}$ wide (FIGS. 2, 3). Ascospores 16.5$25.5 \times 6-9 \mu \mathrm{m}(\bar{x}=20 \times 7 \mu \mathrm{m}, \mathrm{n}=50)$, uniseriate or overlapping uniseriate, fusiform, hyaline, 1-5-septate, thick-walled, straight or slightly curved, with verruculose wall ornamentations at the apical and subapical regions (at TEM level) and with bipolar mucilaginous pad-like appendages (FIGS. 7-10).

Specimen examined. PHILIPPINES. MINDANAO: Bukidnon, Impalutao, Natigbasan Creek, on submerged wood, Jan 1994, K.D. Hyde (HOLOTYPE; HKU(M) 3102).

Etymology. In reference to the fusiform ascospores.

Habitat. Saprobic on wood submerged in freshwater.

Known distribution. The Philippines Islands.

Mature ascospores of $A$. fusiformis are fusiform with rounded mucilaginous pads at each end (FIGS. $11,13)$. These pads appear to be sticky and may aid in ascospore attachment (FIG. 12). Verruculose wall ornamentations are present at the apical and subapical regions of ascospores (FIGS. 11, 12), but are less well developed in the center (FIG. 11).

The wall of a mature ascus is bilamellate comprising an outer electron-dense amorphous layer (OA; 

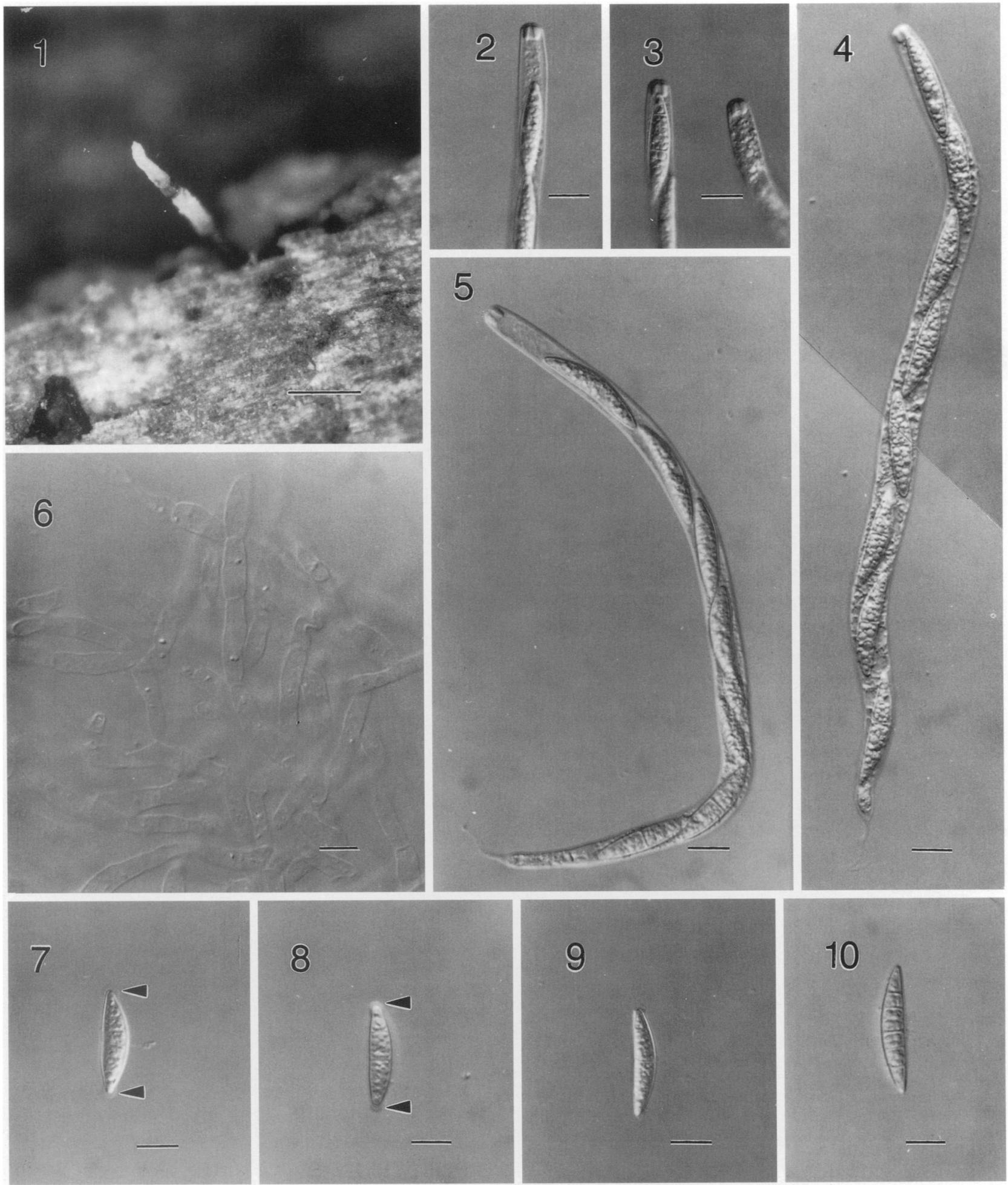

FIGS. 1-10. Annulatascus fusiformis (from HOLOTYPE). Interference light contrast and stereo-micrographs. 1. Immersed ascoma with long neck. 2, 3. Ascus apical rings. 4, 5. Asci, note the relatively massive refractive apical rings. The ascospores are uniseriate or overlapping uniseriate in the asci and the pedicel tapers to a point. 6 . Wide, hyaline, septate paraphyses. 7-10. Hyaline septate ascospores with bipolar mucilaginous pad-like appendages (arrowed). Bars: $1=100 \mu \mathrm{m}, 2-10=10$ $\mu \mathrm{m}$. 

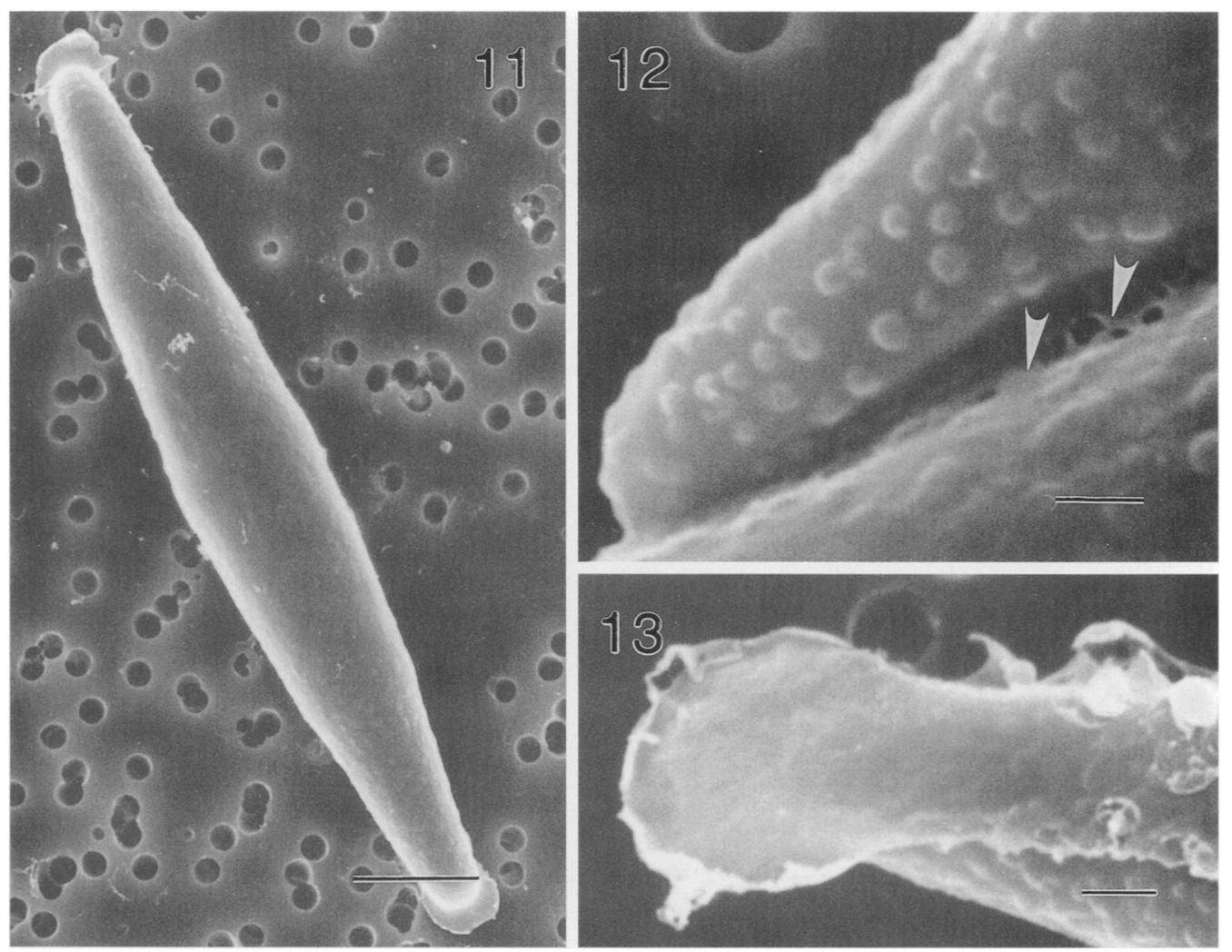

FIGS. 11-13. Annulatascus fusiformis (from HOLOTYPE). Scanning electron micrographs. 11. Fusiform ascospores with polar mucilaginous pads. 12. Two ascospores sticking together due to polar mucilaginous material (arrowed). Note the verruculose wall ornamentations at higher magnification 13. Polar rounded mucilaginous pad of ascospore. Bars: $11=5$ $\mu \mathrm{m}, 12,13=1 \mu \mathrm{m}$.

ca $54 \mathrm{~nm}$ thick), and a thicker inner electron-transparent layer (IA; 0.65-1.80 $\mu \mathrm{m}$ thick; FIGS. 14, 15). The inner wall layer comprises a network of fibrillar material (FN; FIGS. 15, 17) and some electron-dense inclusions (DI; FIg. 14). The apical ring is cylindrical and bipartite (FIG. 16) comprising an upper electrondense part (UR), which appears to be an extension of the outer ascus wall; and a lower electron-transparent part (LR) with horizontally orientated electron-dense fibrils (DF; FIG. 16). A plug (Pg) is present at the level just below the upper part of the apical ring, and extends downwards at its base to form a conical protrusion. The plug is amorphous with similar electron density to that of the inner ascus wall, and both contain fibrillar material (FN) of the same electron density (FIG. 16).

Mature ascospores are fusiform, septate, and are surrounded by a mucilaginous sheath that is thicker at the ends, where they have the appearance of mucilaginous pads (AP; FIGS. 14, 15). In the ascus the mucilaginous pad is closely adpressed to the ascospore wall and is covered by the membrane complex (AP, As, MC; Figs. 14, 15). The appendage comprises closely packed electron-dense aggregates (DA; FIG.
15). Some of these aggregates arise from the edge of the mucilaginous pad and are exosporial in origin (DA: Figs. 15, 17).

The ascospore wall comprises a thin electron-dense episporium (E; ca $40 \mathrm{~nm}$ thick); and a bipartite mesosporium including an outer electron-transparent layer (M1; ca $115 \mathrm{~nm}$ ) with some electron-dense deposits; and an inner more electron-dense layer (M2; ca $346 \mathrm{~nm}$; Figs. 17, 18). The verruculose wall ornamentations (VO) at the apical regions are conical, electron-dense, scattered and may incorporate some smaller and electron-transparent zones (FIG. 17). In the subapical regions, the verruculose wall ornamentations may be flattened and electron-dense throughout (FIG. 18). A less electron-dense layer occurs at the interface between the wall ornamentations and ascospore wall (FIG. 18). The origin of these ornamentations is unknown.

Genera in the Annulatascaceae possess asci with a bipartite apical apparatus (Hyde et al 1998, Ho et al 1999a, b, Wong and Hyde 1999, Wong et al 1998, $1999 \mathrm{~b})$. Most genera also possess ascospores with verruculose wall ornamentations and appendages or sheaths (Wong et al 1998, 1999a). The wall ornamen- 

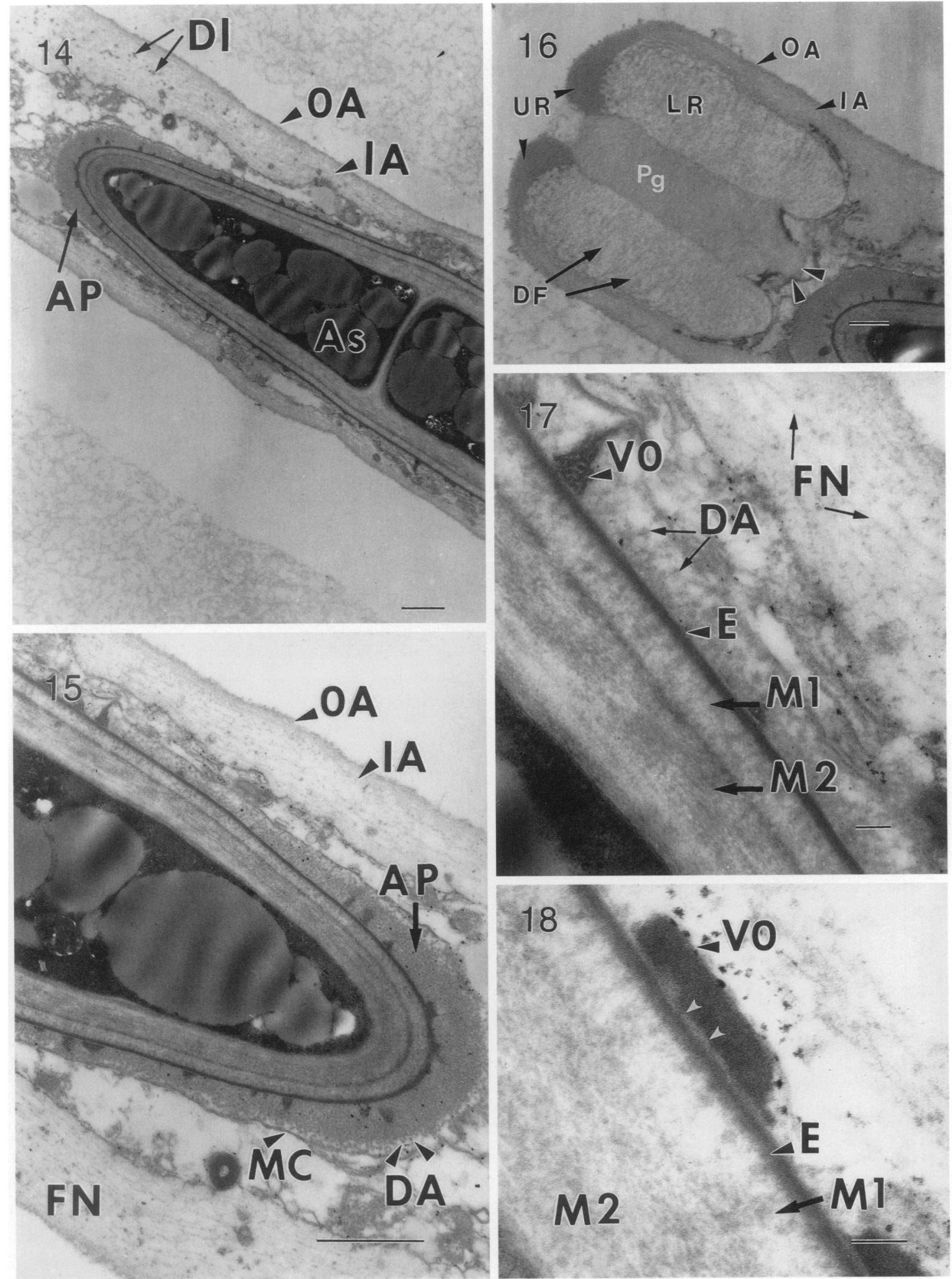

Figs. 14-18. Annulatascus fusiformis (from HOLOTYPE). Transmission electron micrographs. Labels: Ascospore (As), outer thin electron-dense layer of ascus (OA), inner thick electron-transparent layer of ascus (IA), electron-dense inclusions (DI), fibrillar material (FN), mucilaginous pad (AP), membrane complex (MC), electron-dense aggregates (DA), upper electron-dense part of ascus ring (UR), lower electron-transparent part of ascus ring (LR), horizontally orientated fibrillar material (DF), electron-dense amorphous plug material $(\mathrm{Pg})$, conical protrusion at base of plug (arrowed), episporium (E), outer electron-transparent layer of mesosporium with some electron-deposits (M1), inner thick layer of mesosporium with amorphous material (M2), wall ornamentations (VO). Bars: 14-16 =1 $\mu \mathrm{m}, 17,18=0.1 \mu \mathrm{m}$. 
tations can usually only be seen at the SEM level. In Diluviocola K. D. Hyde, S. W. Wong \& E. B. G. Jones (Hyde et al 1998) and Pseudoproboscispora (Wong \& K. D. Hyde) Punith. (Wong and Hyde 1999) ascospores possess bipolar thread-like appendages. In $A n$ nulatascus species, ascospores are surrounded by a mucilaginous sheath and therefore A. fusiformis is better accommodated here (Wong et al 1998).

Hyde and Jones (1989) categorized the ascospore adhesion type of Lautisporopsis circumvestita (Kohlm.) E. B. G. Jones, Yusoff \& S. T. Moss, Ceriosporopsis tubulifera (Kohlm.) Kirk and Ondiniella torquata (Kohlm.) E. B. G. Jones, R. G. Johnson \& S. T. Moss as pad-like. The ascospore appendages of these species either form as direct outgrowths of the episporium ( $O$. torquata), elaboration of the mesosporium (L. circumvestita) or are of unknown origin $(C$. tubulifera). In $A$. fusiformis ascospores have nonextendable pad-like polar appendages. These appendages are continuous around the ascospore, although they cannot be seen in the center at the LM level. At the TEM level, the mucilaginous sheath of the ascospores of $A$. fusiformis comprises electron-dense material. No association of the mucilage material with any ascospore wall layers has been observed in $A$. fusiformis and thus, the appendages are considered to be exosporial in origin.

Annulatascus fusiformis differs from other species in the genus by the conspicuous pad-like appendages (Hyde 1992, 1995, Ho et al 1999a, b, Wong et al $1999 \mathrm{~b})$. It also has unusual verruculose flattened wall ornamentations, as compared to hemispherical in other Annulatascus species (Ho et al 1999a, b, Wong et al 1999b). Thin layers of mucilage occur at the ends of the ascospores of $A$. biatriisporus $\mathrm{K}$. D. Hyde (Hyde 1995), and these could also be described as pad-like. The ascospores in A. biatriisporus, however differ in shape and are larger.

\section{ACKNOWLEDGMENTS}

S. W. Wong would like to thank S. T. Moss for his teaching of electron microscopic techniques and The University of
Hong Kong for the award of a Postgraduate Studentship. We should like to acknowledge the staff in the electron microscopy unit, Queen Mary Hospital, Hong Kong and Helen Leung for technical help and Mr. Lee for photographic assistance. Ho Wai Hong is thanked for his comments and advice on this paper.

\section{LITERATURE CITED}

Goh TK, Hyde KD, Ho WH, Yanna. 1999. A revision of the genus Dictyosporium, with descriptions of three new species. Fung Divers 2:63-99.

Ho WH, Hyde KD, Hodgkiss IJ. 1999a. Ultrastructure of Annulatascus aquaticus sp. nov., a freshwater ascomycete on submerged wood. Fung Divers 2:119-128.

—_, Ranghoo VM, Hyde KD, Hodgkiss IJ. 1999b. Ascal ultrastructural study on Annulatascus hongkongensis sp. nov., a freshwater ascomycete. Mycologia 91:885-892.

Hyde KD. 1992. Tropical Australian freshwater fungi. II. Annulatascus velatispora gen. et sp. nov., A. bipolaris sp. nov. and Nais aquatica sp. nov. (Ascomycetes). Aust Syst Bot 5:117-124.

- 1995. Tropical Australian freshwater fungi. VII. New genera and species of Ascomycetes. Nova Hedwig 61: 119-140.

- Jones EBG. 1989. Observations on ascospore morphology in marine fungi and their attachment to surfaces. Bot Mar 32:205-218.

—, Wong SW, Jones EBG. 1998. Diluviocola capensis gen. et sp. nov., a freshwater ascomycete with unique polar caps on the ascospores. Fung Divers 1:133-146.

Wong SW, Hyde KD. 1999. Proboscispora aquatica gen. et sp. nov. from wood submerged in freshwater. Mycol Res 103:81-87.

- - - Jones EBG. 1998. Annulatascaceae, a new ascomycete family from the tropics. Syst Ascomycetum $16: 17-25$

- -1 - 1999a. Ultrastructural studies on freshwater ascomycetes, Fluminicola bipolaris gen. et sp. nov. Fung Divers 2:195-203.

$-\longrightarrow,-$ Moss ST. 1999b. Ultrastructural studies on Annulatascus velatisporus and A. triseptatus sp. nov. Mycol Res 103:561-571. 